\title{
Planning and Sustainable Land Management in England's National Parks
}

\author{
Nicola Thompson, Guy Garrod \& Marian Raley \\ Keywords: planning, sustainable land use, inhabited protected areas, English national parks
}

\section{Abstract}

The English national parks are IUCN Category V protected areas. The governance of the parks is structured to achieve two purposes: 1) to conserve and enhance the natural beauty, wildlife and cultural heritage and 2) to promote opportunities for the understanding and enjoyment of the special qualities. There is also a secondary duty to foster the economic and social well-being of local communities within the park areas. This report examines the ways in which statutory planning processes have contributed to sustainable land use in the inhabited national parks of England.

\section{Introduction}

The English national parks system was founded following the 1949 National Parks and Access to the Countryside Act. Seven national parks were designated in upland England in the 1950s. These areas are relatively mountainous in the English context, although the highest point in any of the parks is only 978 metres. A lowland area (The Broads) was effectively added in the 1980s with two new lowland parks designated since 2005.

Parks now cover $9.3 \%$ of the land area of England. There is no national administration of the parks as such. Instead, each park is governed by a free standing, special purpose local authority (or municipality) known as a National Park Authority (NPA). England's national parks comprise some of the longest established IUCN category V protected areas in Europe.

Since designation the statutory planning system has been central to the pursuit of the park purposes. Planning powers are the principal regulatory mechanism that the authorities can use. While there are various public bodies involved in park management, NPAs have the lead responsibility for achieving the purposes and duty. NPAs exist alongside conventional local municipalities who deliver a range of services in the park areas. All NPAs are responsible for statutory planning processes, including development control (planning decisions) and strategic (or long term) planning in the park areas. Unlike other local planning authorities, NPAs have a statutory duty to implement management plans, which they deliver in partnership with a range of other stakeholders.

The English national parks system is the result of a complex history that has involved many compromises. Proponents of the system fought hard for NPAs to have planning powers, believing them to be vital to landscape conservation, while those who opposed designation feared the impact of tighter planning controls on local communities (MacEwen \& MacEwen 1982). It is therefore imperative to question the role of planning in the sustainable management of these inhabited designations in any appraisal of the English system. The long history of the English experience makes such appraisal relevant to international debates on the effective management of Category $\mathrm{V}$ protected areas. Therefore, in this report we question the extent to which planning functions assist with achieving sustainable land management.

\section{Insights from the literature}

The MacEwens $(1987,1982)$ and Blunden \& Curry (1989) provide comprehensive overviews of the parks system, tracing why planning powers have been so significant to authorities and the role of planning in shaping the evolution of park landscapes. Whether designation makes a difference in planning decisions was the topic of a 1992 paper by Nigel Curry. He examined time series data on planning applications and refusals. The research found that between the early 1960s and early 1970s refusal rates were similar to national trends. During the 1970 s and 1980 s refusal rates were higher in parks than nationally, although there was a significant degree of variation between years and parks (Curry 1992: 116). Today it is the perception, if not the reality, that planning in the parks is more restrictive. Official statistics for 2010 and 2011 show that approval rates are about the same as the national average. There are significant differences between the parks, with the majority of applications being made in the lowland parks designated since 2005 and the majority of the parks experiencing relatively low levels of development pressure. Although approval rates follow national trends, the literature suggests that there are distinctive features associated with planning practice in the parks which influence the approaches to sustainable development found within the designations:

- Research has found that design standards are very high. The conservative approaches adopted in national parks often preclude the introduction of modern architecture (Land Use Consultants 2001). There is very low demand for new commercial and industrial development. Researchers have argued that this is partly as a result of an unwilling on the part of decision makers to conceptualize development as capable of enhancing natural beauty, despite an acceptance amongst planners that park 
purposes rely on a sound rural economy (Lloyd et al. 2004, p. 293).

- Conservation interests have tended to dominate public consultations on planning matters (Lloyd at al. 2004).

Affordable housing has been built in the national parks but the experience is variable across the parks. For example, Richards and Satsangi (2004) found ample evidence of housing need in their case study park but also found that planning policy restricted new development, with the only sites allocated for new housing being in a single town. Elsewhere, routes to provision were very limited. They argued that designation had restricted access to affordable housing by inflating house prices and limiting supply of land to exception sites in their case study.

Hence, while the overall approval rate, though low, is in line with the national average, the literature suggests important differences in the ways in which planning operates in national parks, in particular the dominance of broadly defined conservation interests in determining what constitutes acceptable development.

\section{Planning and sustainable land manage- ment}

Perhaps reflecting the influence of conservation interests, there is a strong case for arguing that planning has conserved the natural beauty of the park landscapes since designation. Indeed, critics often argue that preserving a particular landscape aesthetic has been so successful that the parks are being preserved in aspic rather than evolving to reflect changing nature / human interactions. The planning system can also be argued to be effective with regard to cultural heritage if this is interpreted to mean the built heritage. However, the relationship between planning and biodiversity conservation is more complex. Low levels of new development mean that controversies over the impact on particular habitats are relatively rare. The English system also places limits on the regulatory powers of planners with regard to land management. There are few regulatory means of influencing agricultural practices beyond special types of designation and particularly damaging activities. Instead, park managers have to work outside the statutory planning system to cooperate with farmers and encourage them into positive environmental activities. This is principally through pillar two of the Common Agricultural Policy. Hence, while on a landscape conservation scale planning is important in many respects, sustainable land management relies on a fuller set of European policy instruments.

It is increasingly well understood that sustainable land management in Category $\mathrm{V}$ protected areas relies on the economic and social wellbeing of the communities and individuals who undertake their management. Hence planning has an important role to play in the English national parks as one of the tools through which the socio-economic duty can be achieved. Two broad bodies of thought on the role of the planning system with regard to the duty can be discerned. These are articulated by NGOs, officers and staff of NPAs, community representatives, politicians, as well as researchers and journalists. Some of those involved in national parks highlight the tensions between development and conservation. They are often concerned that the duty results in the dilution of the two traditional purposes. Often they voice a fear that developers will attempt to use the duty to override the purposes and damage the special qualities. But those who are cautious about the effect of the duty have frequently acknowledged that some forms of development should be accommodated and that socioeconomic development in certain forms should be encouraged. Often those who are cautious are sympathetic to community need but emphasize the economic benefits of conservation. The first group tends to argue that planning functions should be exercised to maintain a tight control over development.

The second group focuses on the role of planners in encouraging appropriate business and community development. They tend to have the view that more positive action would mean that the statutory purposes would be promoted through development. While aware of potential tension between purposes, this group seeks to find complementarities. They take a view of planning which emphasizes collaboration, the need to work with others to achieve the purposes and the duty. This perspective is also linked with an understanding that the landscapes and habitats that the designation is seeking to protect are the product of nature / culture interactions and rely on traditional forms of management to be environmentally sustainable.

The duty has been in place since 1995 (The Environment Act 1995, 61). It continues to attract debate and evidence on its impacts is mixed. NPAs can point to evidence that planners and other officers have used the duty to positive effect in ways which help to achieve the purposes. However, some critics say that too little has been achieved and want the elevation of the duty to a full purpose. Other critics, especially those in the first group, remain sceptical that the duty is of value and point to the potential ways in which it can be used by developers.

\section{Conclusions}

Thinking on the objectives and societal role of protected areas has changed over the last two decades (Mose 2007). The English national parks system designed in the 1950s has evolved to reflect some of these changes but managers work in the context of the powers given to them under the 1949 Act (as amended by some more recent relatively minor legislative changes). Planning remains the primary regulatory mechanism through which the purposes can be achieved, with 
other areas of activity usually relying on discretion, facilitation and partnership. The introduction of the duty in 1995 has brought into sharper focus a debate on how NPAs should approach the implementation of planning powers in a context of achieving sustainable development. This debate remains active with different authorities reflecting different mixes of the two bodies of thought outlined above.

This brief paper has questioned the extent to which planning functions assist with achieving the sustainable land management in some of the longest established Category V designations in Europe. Planning powers have been vital to the English NPAs. They give the authorities responsibilities and powers which have substantial impacts on the sustainability of the park designations. In 2013 there are times when the ability to say yes or no remains crucial, but it is most powerfully exercised when working collaboratively and when the decision is seen to take into account all dimensions of sustainability. Planning is a necessary power to achieving the purposes and the duty but it is not sufficient to achieve sustainable land management. The English experience shows that, alongside planning powers, managing authorities need a range of other tools to sustain the future of protected areas.

\section{References}

Blenkinsop, A. 1964. The National Parks of England and Wales. Journal of Environmental Planning and Management series 1 (6): 9-75

Blunden, J. \& N. Curry (eds.) 1989. A People's Charter? Forty years of the National Parks and Access to the Countryside Act, 1949. Countryside Commission, Cheltenham

Brotherton, I. 1982. Development Pressures and Control in the National Parks 1966 - 1981. Town Planning Review 53: 439-459

Curry, N. 1992. Controlling development in the National Parks of England and Wales. Town Planning Review 63: 107-121.

Land Use Consultants 2001. Development Planning and Control in National Parks in England and Wales, Scottish Executive, Edinburgh
Lloyd, G., J. McCarthy \& B. Illsley 2004. Commercial and Industrial Developments in National Parks in England and Wales: Lessons for the Scottish Agenda. Journal of Environmental Policy and Planning 6: 289-304

MacEwen, M. \& A. MacEwen 1987. Greenprints for the Countryside - The Story of Britain's National Parks. Hemel Hempstead

MacEwen, M. \& A. MacEwen 1982. National Parks: Conservation or Cosmetics? Hemel Hempstead

Mose, I. (ed.) 2007. Protected Areas and Regional Development in Europe: Towards a New Model for the $21^{\text {st }}$ Century. Aldershot.

Patmore, A.J. 1987. A Case Study in National Park Planning. In Cloke, P. (ed.), Rural Planning: Policy into Action? London

Richards, F. \& M. Satsangi 2004. Importing a Policy Problem? Affordable Housing in Britain's National Parks. Planning Practice and Research 19: 251-266.

The Environment Act 1995. Available from: http://www.legislation.gov.uk/ukpga/1995/25/ contents (accessed: 18/11/2013)

\section{Authors}

\section{Nicola Thompson}

is a lecturer at Newcastle University's Centre for Rural Economy. Her research interests are in protected areas and the governance of rural areas.

\section{Guy Garrod}

is Director of Newcastle University's Centre for Rural Economy. He is an environmental economist with interests in land management, agri-environment policy and the economic valuation of environmental goods and services.

\section{Marian Raley}

is an applied social scientist with interests in agriculture and the rural economy. With a background in both natural and social sciences, she has extensive experience in policy-relevant cross-disciplinary research. 